\title{
EMPYEMA THORACIS IN CHILDREN: A CLINICAL STUDY
}

\author{
Narendra Laishram1, Daizy Ngangom² \\ ${ }^{1}$ Assistant Professor, Department of Paediatrics, JN Institute of Medical Sciences. \\ ${ }^{2}$ Senior Resident, Department of Paediatrics, JN Institute of Medical Sciences.
}

\section{ABSTRACT}

\section{BACKGROUND}

Empyema thoracis is a disease that despite centuries of study still causes significant morbidity and mortality.

\section{AIMS}

To study the age-sex profile, clinical presentation, etiologic agents, management and the overall treatment outcome of empyema thoracis in children.

\section{METHODOLOGY}

A total of 25 patients of both the sexes aged 0-12 years diagnosed to have empyema thoracis and who underwent tube thoracostomy from March 2013 to February 2014 were studied. Detailed clinical history, physical examination, relevant routine and specific investigation were done. The pleural fluid was studied for gram staining, microscopy, cytology, pleural fluid culture and antibiotic sensitive pattern. All the patients were treated with tube thoracostomy and antibiotic therapy depending on the culture and sensitivity pattern. Complications were recorded.

\section{RESULTS}

Majority of patients $(0.64 \%)$ were seen in age group of $1-5$ years. Fever (96\%), breathlessness (92\%), and cough (72\%) were the commonest presenting features. Bacteriological examination revealed staphylococcus aureus as the commonest etiologic agent $(20 \%)$ isolated from pleural fluid culture. Pyopneumothorax (16\%) was the commonest complication seen in these patients. All patients (92\%) were treated with antibiotics, and drainage of the empyema was effected by closed thoracostomy in (92\%) of the cases. There was no mortality.

\section{CONCLUSION}

Empyema is not rare in our practice. Early diagnosis and proper treatment of pneumonia prevent the development of empyema. Antibiotics and tube thoracostomy is an effective method of treating pyogenic empyema thoracis in children in resource poor settings.

\section{KEYWORDS}

Tube Thoracostomy, Empyema Thoracis, Parapneumonic Effusion.

HOW TO CITE THIS ARTICLE: Laishram N, Ngangom D. Empyema thoracis in children: a clinical study. J Evolution Med Dent Sci 2016;5(1):46-49, DOI: 10.14260/jemds/2016/11

\section{INTRODUCTION}

Hippocrates in 600 B.C. defined empyema thoracis as a collection of pus in the pleural cavity and advocated open drainage as its treatment.(1) Empyema thoracis, a common condition in childhood. $(2,3)$ and has significant morbidity and mortality. Empyema thoracis constitutes approximately 5$10 \%$ of cases seen by pediatrician in India. $(4,5)$

Acute respiratory infections are the most common illness of childhood accounting $50 \%$ of all illness in under-fives and $30 \%$ in the 5-12 years age groups, largely involving the upper respiratory. However, about $5 \%$ involve the lower respiratory tract resulting in serious diseases, especially the bacterial pneumonia.(6) Forty percent of bacterial pneumonia are said to be complicated by parapneumonic effusions, $10 \%$ of whom would evolve into empyema. (7) Possible reason for this include delay in initiating treatment, prolonged oral treatment in the community with antibiotics inadequate drug level in the pleural space and delayed presentation, or unusual casual organism.(8)

Financial or Other, Competing Interest: None.

Submission 23-12-2015, Peer Review 24-12-2015,

Acceptance 29-01-2016, Published 02-01-2016.

Corresponding Author:

Dr. Narendra Laishram,

JN Institute of Medical Sciences,

Imphal.

E-mail: drlnarendra@gmail.com

DOI:10.14260/jemds/2016/11
It is a significant cause of pediatric hospital admissions and morbidity especially in developing countries where hospital resources are scarce. $(9,10,11)$

The proper management of empyema thoracis in children continues to be a source of debate. It continues to have a high mortality rate $10-16 \%$.(12) Pleural effusion and empyema are known complications of bacterial pneumonia. Effusion occur in at least $40 \%$ of bacterial pneumonia with up to $60 \%$ of effusions resulting in the formation of empyema in all age groups.(13,14) The American Thoracic Society has described three stages of empyema namely exudative, fibrinopurulent and organized.(15) It is postulated that most appropriate therapy depends on stage of disease at presentation.

Staphylococcus aureus is the most common cause of in the developing world, while streptococcus pneumonia in the developed world. $(16,17,18)$ The reported rates of identifying an infectious cause from pleural fluid vary from between $8 \%$ and $16 \%$ respectively. Pleural fluid is sterile due to widespread early use of antibiotics. $(19,20)$

The aim of therapy is to ensure rapid recovery with a normal long-term pulmonary outcome. Medical therapy includes use of antibiotics and chest tube drainage. More recently, early intervention in the form of Video-Assisted Thoracoscopic Surgery (VATS) has been reported. 


\section{MATERIAL AND METHODS}

This was a prospective observational study, conducted in the Department of Pediatrics, JNIMS, Imphal, from March 2013 to Feb 2014. The study was approved by the Institute's Ethical Committee and written informed consent was obtained from all patients. All children in age group of 0 to 12 years diagnosed pyogenic empyema during the study period were included in the present study. Children with empyema secondary to postsurgical cause or post traumatic cause were excluded from the study.

The diagnostic criteria for empyema thoracis was presence of pleural effusion, clinical and radiological examination and aspiration of pus from the thoracic cavity. A detailed history was taken regarding complaints, predisposing factors, immunization and communications. Detailed general and systemic examination done. Routine and relevant specific examinations were done. These include hemoglobin estimation, total leukocyte count, ESR, HIV. All patients suspected of pleural effusion clinically were subjected to chest X-ray, USG and (If required) CT thorax. Other investigations includes pleural tap fluid was studied for gram staining, microscopy cytology biochemical analysis including protein estimation, pleural culture and antibiotic sensitivity pattern. A chest radiograph (PA or AP) and a lateral view if indicated were done after chest tube insertion. Intercostal drainage with tube thoracostomy was performed in all patients.

All patients received supportive treatment and were empirically administered ceftriaxone, cloxacillin and amikacin as first line antibiotics in appropriate doses. Subsequent management including choice and duration of antibiotics was determined by clinical progress of the patients and availability of pus culture and sensitivity results. Change of antibiotic was considered in case of clinical non-improvement after 5 days of initial antibiotic therapy and effective drainage and in the absence of a positive culture report, the second line antibiotic used were piperacillin-tazobactam and vancomycin. Clinical non-improvement was defined as persistence of sepsis indicated by fever spikes, poor oral intake and rising TLC. Antibiotics were given for 4 weeks or longer (If required): a minimum of 2 weeks of injectable antibiotics or till 1 week after disappearance of fever, whichever was later.

The patient requiring prolonged hospitalization and who did not respond to conventional antibiotics and tube thoracostomy or developing complications or those not showing radiological signs of lung expansion were referred to the pediatric surgeon for thoracoscopic decortications or VATS. All patients were studied for complications during hospital stay.

At each follow-up, patients were assessed clinically and subjected to chest radiography.

\begin{tabular}{|c|c|c|}
\hline Age Group (Years) & Number of Cases & Percentage \\
\hline $0-1$ & 3 & 0.12 \\
\hline $1-5$ & 16 & 0.64 \\
\hline $6-12$ & 6 & 0.24 \\
\hline \multicolumn{3}{|c|}{ Table 1: Age distribution of the 25 Empyema Cases } \\
\hline
\end{tabular}

\section{SEX DISTRIBUTION}

\begin{tabular}{|c|c|c|}
\hline Sex & Number of Cases & Percentage \\
\hline Male & 17 & 68 \\
\hline Female & 8 & 32 \\
\hline
\end{tabular}

UNDERLYING PREDISPOSING RISK FACTORS FOR EMPYEMA THORACIS

\begin{tabular}{|c|c|c|}
\hline & $\begin{array}{l}\text { Number of } \\
\text { Cases }\end{array}$ & Percentage \\
\hline 1. Measles & 2 & 8 \\
\hline 2. Bronchopneumonia & 5 & 20 \\
\hline $\begin{array}{l}\text { 3. Impetigo and other } \\
\text { skin lesion }\end{array}$ & 3 & 12 \\
\hline 4. Tuberculosis & 2 & 8 \\
\hline Total & 12 & 48 \\
\hline
\end{tabular}

\section{Nutritional Status}

\begin{tabular}{|c|c|c|}
\hline $\begin{array}{c}\text { Grade of } \\
\text { Malnutrition }\end{array}$ & $\begin{array}{c}\text { Number of } \\
\text { Malnutrition }\end{array}$ & Percentage \\
\hline 1. No Malnutrition & 5 & 20 \\
\hline 2. PEM I & 3 & 12 \\
\hline 3. PEM II & 10 & 40 \\
\hline 4. PEM III & 6 & 24 \\
\hline 5. PEM IV & 1 & 4 \\
\hline Total & 25 & 100 \\
\hline
\end{tabular}

\begin{tabular}{|l|c|c|}
\hline Manifestations & $\begin{array}{c}\text { Number of } \\
\text { Cases }\end{array}$ & Percentage \\
\hline 1. Fever & 24 & 96 \\
\hline 2. Breathlessness & 23 & 92 \\
\hline 3. Cough & 18 & 72 \\
\hline 4. Chest Pain & 8 & 32 \\
\hline $\begin{array}{l}\text { 5. Anorexia, Malaise, } \\
\text { weight loss }\end{array}$ & 12 & 48 \\
\hline
\end{tabular}

Table 2: Presenting symptoms in patients with Empyema Thoracis

BACTERIOLOGICAL PROFILE/PUS CULTURE RESULTS

\begin{tabular}{|ll|c|c|}
\hline \multicolumn{1}{|c|}{ Organism } & Number & Percentage \\
\hline 1. & No growth & 16 & 64 \\
\hline 2. Staphylococcus aureus & 5 & 20 \\
\hline 3. Streptococcus pneumoniae & 2 & 8 \\
\hline 4. Klebsiella pneumoniae & 1 & 4 \\
\hline 5. & Pseudomonas & 1 & 4 \\
\hline
\end{tabular}

\section{Complications}

\begin{tabular}{|l|c|c|}
\hline \multicolumn{1}{|c|}{ Complications } & Number & Percentage \\
\hline 1. Pyopneumothorax & 4 & 16 \\
\hline 2. Pneumothorax & 2 & 8 \\
\hline 3. Subcutaneous emphysema & 1 & 4 \\
\hline
\end{tabular}

Response to various modalities of treatment.

\begin{tabular}{|c|c|c|}
\hline Procedure & No. of Cases & Percentage \\
\hline $\begin{array}{c}\text { Antibiotic + Tube } \\
\text { thoracostomy }\end{array}$ & 23 & 92 \\
\hline Decortications & 1 & 4 \\
\hline VATS & 1 & 4 \\
\hline
\end{tabular}

Outcome of Emphysema Thoracis in study children $(\mathrm{N}=25)$

\begin{tabular}{|c|c|c|}
\hline Duration (d) & Number & Percentage (\%) \\
\hline \multicolumn{3}{|c|}{ Chest Tube } \\
\hline$<8 \mathrm{~d}$ & 8 & 24 \\
\hline $8-30 \mathrm{~d}$ & 15 & 60 \\
\hline$>30 \mathrm{~d}$ & 1 & 4 \\
\hline \multicolumn{3}{|c|}{ Hospital Stay } \\
\hline$<14 \mathrm{~d}$ & 17 & 68 \\
\hline $14-30 \mathrm{~d}$ & 6 & 24 \\
\hline$>30 \mathrm{~d}$ & 2 & 4 \\
\hline
\end{tabular}




\section{RESULTS}

The general characteristic of these patients of empyema thoracis are shown in Table 1.A total of 25 patients were included in the study, male $17(68 \%)$, female $8(32 \%)$. Majority of cases of empyema occurred in the age group 1-5 years comprising $(0.64 \%)$ of cases and male outnumbers female. Thus the male-to-female ratio was 2.1:1.Seven patients (28\%) were residents of urban areas and 18 patients (72\%) belonged to rural areas and most of them belonged to low socioeconomic strata. Certain predisposing factors are studied like measles, bronchopneumonia and skin lesions. Bronchopneumonia (20\%) was found to be the commonest predisposing factor.

Nutritional status was assessed as per Indian Academy of Pediatrics (IAP) classification of malnutrition. Majority of patients were of grade II (40\%), followed by grade III and grade IV i.e. $24 \%$ and $4 \%$ respectively. The results of study of empyema thoracis were shown in Table II. The commonest symptoms at presentation were fever (96\%), breathlessness (92\%), cough (72\%) followed by chest pain (32\%). In addition constitutional symptoms viz anorexia, malaise and weight loss were noted in 12 patients (48\%).

Pleural fluid culture were positive in 9 (36\%) patients. Five patients $(20 \%)$ had gram positive cocci in clusters in gram stain, but a negative culture. The most frequently isolated micro-organism was staphylococcus aureus 5 (20\%). Other micro-organisms were streptococcus pneumoniae (8\%), pseudomonas (4\%), Klebsiella pneumoniae (4\%). Pleural fluid cultures were sterile in $64 \%$ of patients.

The commonest complication associated in these patients was pyopneumothorax (16\%) as shown in Fig 2 . The associated complications after start of treatment were improper position (12\%), thickened pleura (4\%), pyopneumothorax $(4 \%)$. Eighteen $(72 \%)$ patients received antibiotics (Oral plus parenteral) for 4 weeks and seven (28\%) received for a period greater than 6 weeks. A chest X-ray was obtained after insertion of chest tube to confirm the position of the chest tube. The chest tube was removed when there was no drain or minimal drain $<20 \mathrm{~mL} /$ day for two consecutive days with a patent tube. Overall, of 25 patients 23 (92\%) cases managed with tube thoracostomy. One case managed with decortication and another case with VATS (Video assisted thoracoscopic surgery). In outcome, all patients survived (100\%).

\section{DISCUSSION}

Though the incidence of empyema thoracis has declined in the west due to effective use of broad spectrum antibiotics, but it still remains a significant health problem in developing countries due to low socioeconomic status, malnutrition and delay in diagnosis of pneumonia, delayed referral to higher centre.

Therapy for thoracic empyema requires appropriate antibiotics, prompt drainage of the infected pleural space and lung expansion. However there is no clear consensus on the best way to obtain these objectives. $(21,22,23)$

The age of presentation and male preponderance was consistent with similar other studies.(17,24,25) The higher prevalence in under-fives $(0.64 \%)$ and the slight male preponderance $(2.1: 1)$ is in general agreement with the established pattern of acute lower respiratory infections in children.(6)
Out of many predisposing factors studied, bronchopneumonia found to be the most commonest as in other studies done.(26,27) In our study, $80 \%$ of the children were malnourished as per IAP classification.(28) Fever, breathlessness and cough were the most common (90\%) manifestations found at admission similar to many other studies.(29,24,25) Other associated manifestations were anorexia, malaise and weight loss.

A higher incidence of empyema cases were seen more often in malnourished children as seen in this study, similar to other studies conducted in developing countries. $(30,31,32,33)$ Predisposition of malnourished children to recurrent, severe and complicated infection is a known factor.

In our study, pleural fluid culture showed bacterial growth in $36 \%$ of patients and no growth in $64 \%$ of patients.(24) The present study culture reports were similar to other reports. Most common organism isolated was staphylococcus aureus which is comparable to previous studies from other developing countries.(29,24,25,34,35) Other causes are streptococcus pneumoniae, pseudomonas and Klebsiella pneumoniae. The sterile sample might be due to high rate of antibiotics pre- treatment or lack of better facilities for culturing fastidious organism like anaerobes. Pneumococcus is the major pathogen in developed countries. $(17,18)$

White blood cell count of parapneumonic effusions is known to be a non-reliable parameter in the diagnosis of patients with empyema.(7) Similar findings were observed in four of our patients (16\%) who had pleural WBC count $<10,000 \mathrm{~mm}^{3}$ in the presence of positive results on bacteriologic studies. This emphasizes the need for microbiologic examination of suspected pleural fluid even though cell counts are low.

The median duration of hospital stay was comparable to other studies on conservative management.(36,37,38) In the present study, all patients responded to conservative management and one patient required decortication and one requiring VATS. Previous studies suggest a success rate of 61 $100 \%$ with chest tube drainage and antibiotics.(39,40) These treatment outcome were similar to other studies.(21,29)

A meta-analysis comparing operative and non- operative procedures has also concluded that conservative management leads to recovery in more than $76 \%$ of the patients. Average duration of antibiotics used in this study was longer than the previously reported studies from developed countries.(37,38) The reason for this could be a higher incidence of staphylococcal infection in our study that required a longer duration of therapy as compared to streptococcal and $\mathrm{H}$. influenza infection. The choice of antibiotics was governed by the culture and sensitivity pattern prevalent in that particular region. The complications on admission were studied, pyopneumothorax was the commonest associated complication with empyema followed by pneumothorax. In the treated patients of empyema thoracis, thickened pleura were the commonest complications. There was no case fatality rate in this study. This outcome is similar to other studies done where $100 \%$ is the survival.(41) Recovery and long-term outcome is good with appropriate treatment. However, in the present study complete pleural recovery could not be documented due to shorter period of followup and was a major limitation. Spirometry could not be done for a majority of the patients because of a younger age and was a limitation. 


\section{REFERENCES}

1. Adams F. The genuine works of Hippocrates, Baltimore: William and Wilkins Company; 1939;51-2.

2. Eastham KM, Freeman R, Kearns AM, Eltringham G, Clark $\mathrm{J}$, Leeming J, et al. Clinical features, aetiology and outcome of empyema in children in the North East of England. Thorax. 2004;59:522-5.

3. Roxburg CSD, Young Son GG, Towend JA, et al. Trends in pneumonia and empyema in Scottish children in the past 25 years. Arch Dis Child. 2008;93:316-8.

4. YC 5. Jeffery M Bender, Krow Ampofo, Xiaoming Sheng, Andrew T Pavia, Lisa Cannon-Albright and Carrie L Byington. Parapneumonic empyema deaths during past century. Utah Emerg Infect Dis. January 2009;15(1):44-48.

5. Phelan, Landau PC, L. I. and Olensky A. Respiratory illness in children. Blackwell scientific publications. Second Edition, 1982;29-47.

6. Light, RW. Management of parapneumonic effusions, J Empyema thoraces during a 10-year period (1952-67). Arch Ins Med 1981;141:1771-1776.

7. Peter Mattei, Julian L Allen. Treatment of empyema in children from Hippocrates' time to the present and back again. Editorial Am J Res Crit Care Med 2006;174:110-111.

8. Maziah W, Chook E, Ray JG, et al. Empyema thoracis in hospitalized children in Kelantan, Malaysia. J Trop Pediatr 1995;41:185-8.

9. Mishra OP, Das BK, Jain AK, Lahiri TK, Sen PC, Bhargara V. Clinico-bacteriological study of empyema thoracis in children. J Trop Pediatr 1993;39:380-1.

10. Asendi AA, Estem SE, Asuquo ME. Clinical and bacteriological study on childhood empyema in South Eastern Nigeria, East Afr Med J 1992;69:78-82.

11. Anstadt MP, Guill CK, Ferguson ER, Gordon HS, Soltero ER, Beall AC Jr, et al. Surgical versus no surgical treatment of empyema thoracis-An outcome analysis. Am J Med Sci 2003;326:9-14.

12. Strange C, Tomlinson JR, Wilson C, Harley R, Miller KS, Sahn SA. The histology of experimental pleural injury with tetracycline, empyema and carragunan. Exp Mol Pathol. 1999;51:205-19.

13. Givan DC, Elgen H. Common pleural effusions in children. Clin Chest Med. 1998;19:363-71.

14. The American Thoracic Society Subcommittee on Surgery. Management of non-tuberculous empyema. Am Rev Respir Dis. 1962;85:935-6.

15. Narayanappa D, Rashmi N, Prasad NA, et al. Clinicobacteriological profile and outcome of empyema. Indian Pediatr. 2013;50:783-5.

16. Byington CL, Spencer LY, Johnson TA, Pavia AT, Allen D, Mason EO, et al. An epidemiological investigation of a sustained high rate of pediatric parapneumonic empyema: Risk factors and microbiological associations. Clin Infect Dis. 2002;34:434-40.

17. Estham KM, Freeman R, Kearns KM, Eltringham G, Clark J, Leeming J. Clinical features, aetiology of empyema in children in the North East of England. Thorax. 2004;59:522-5.

18. Dass R, Deka NM, Barman H, Durwarah SG, Khyriem AB, Saikia MK, et al. Empyema thoracis: analysis of 150 cases from a tertiary care centre in North East India. Indian J Pediatr. 2011;78:1371-7.
19. Sarihan H, Cay A, Aynaci M, et al. Empyema in children. J Cardiovasc Surg (Torino). 1998;39:113-6.

20. Strange C, Sahn SA. The clinician's perspective on parapneumonic effusions and empyema. Chest. 1993;103:259-61.

21. Tiryaki T, Abbasoglu L, Bulut M. Management of thoracis empyema in childhood: A study of 160 cases. Pediatr Surg Int. 1995;10:534-6.

22. Cham C, Haq SM. Rahamim J Empyema thoracis: a problem with late referral? Thorax. 1993;48:925-7.

23. Vikas G, Ajay K, Monika G, et al. Empyema thoracis in children: Still a challenge in developing countries. Afr J pediatr surg. 2014;11:206-210.

24. Zel SK, Kazeza, Kilic M, Koseogullaric AA, Yelmaza, Aygun AD. Conservative treatment of post parapneumonic thoracic empyema in children. Surg Today. 2004;34(12):1002-5.

25. Singh V. IAP Textbook of Paediatrics, $5^{\text {th }}$ edn, Jaypee Publishers. 2013;478-80.

26. Mangte EDO, Kombo BB, Legg-Jack TE. Thoracic empyema: A study of 565 patients. Arch Dis Child. 1993;69:587-88.

27. Nutrition subcommittee of Indian Academy of pediatrics: Report of convener. Indian Pediatr. 1972;9:360.

28. Satpathy SK, Behera CK, Nanda P. Outcome of parapneumonic empyema. Indian J Pediatr.2005;72:195-9.

29. Hailu S, MD. Paediatric thoracic empyema in an Ethiopian referral hospital. East Afr Med J 2000;77:618-621.

30. Yilmaz E, Dugan Y, Aydinoglu AH, et al. Parapneumonic empyema in children: conservative approach. Turk J Pediatr. 2002;44:134 -8.

31. Menon P, Rao KL, Singh M, Venkatesh MA, Kanojia RP, Samujh R, et al. Surgical management and outcome analysis of stage III pediatric empyema thoracis. J Indian Assoc Pediatr Surg. 2010;15:9-14.

32. Ekpee EE, Akpan MU. Poorly treated bronchopneumonia with progression to empyema thoracis in Nigerian children. TAF Prev Med Bull. 2010;9:181-6.

33. Shah K, Shaikh F, Poddutoor PK, et al. Clinical profile of empyema in tertiary health care centre. Indian J Child Health. 2015;2(1):5-8.

34. Potts DE, Levin DC, Sahn SA. Pleural fluid $\mathrm{pH}$ in parapneumonic effusions. 1976;70(03):328-31.

35. Jigui YU, Douglas Salmon, Mario Marcon, et al. Pneumococcal serotype causing pneumonia with pleural effusion in pediatric patients. Journal of Clinical Microbiology. J Clin Microbiol. February 2011; vol. 49(2):534-536.

36. Satish B, Bunker M, Seddon P. Management of thoracic empyema in childhood: does pleural thickening matter? Arch Dis Child. 2003;88:918-21.

37. McLaughlin JF, Goldman DA, Rosenbaum DM. Empyema in children: clinical course and long-term followup. Pediatrics. 1984;73:587-89.

38. Chan PWK, Crawford O, Wallis C, et al. Treatment of pleural empyema. J Paediatr Child Health.2000;36:375-7

39. Adam Jaffe, Ian M. Management of empyema in children. Pediatric Pulmonology. 2005;40:148-56.

40. Baranwal AK, Singh M, Maratha RK, et al. Empyema thoracis: a 10year comparative review of hospitalized children from South Asia. Ach Dis Child. 2003 Nov;88(11):1009-14.

41. Grisario-Soen G, Eisenstadt M, Parit G, Schwartz D, Keller N, Nagar $\mathrm{H}$, et al. Pediatric parapneumonic empyema: risk factors clinical characteristics, microbiology and management. Pediatr Emerg Care.2013 Apr;29(4):425-9. 